\title{
Influence of Immersion Period on the Corrosion Behavior of Heat Treated Biomedical Alloy Ti -5Al - 2.5Fe
}

\author{
Abdulsalam K. Swadi* Thair L.AL-Zubidy* Kadem K. Ghudaib ${ }^{* *}$ \\ Murtda A.Siyah. *** Basher A.Abd-Alhasan $* * * *$
}

\begin{abstract}
:
Date of acceptance $4 / 12 / 2008$

Heat treatment by solid solution method in the $\alpha+\beta$ phase region was used at $970^{\circ} \mathrm{C}$ for Ti-5 Al-2.5Fe alloy. The specimens cooled under different cooling media [water quenched (WQ), air cooled (AC) and furnace cooled (FC)], and subsequently aged at $550^{\circ} \mathrm{C}$ for 4 hours. Five specimens from each treatment were immersed in simulated body fluid SBF for a period of time (3 months). The dependence of corrosion rate on compositional variation in the phases resulted from various type of cooling rates are discussed based on immersion tests. The EDXA results show the precipitation of phosphate and calcium compounds on the alloy after 3 months of immersion in blood plasma solution forming a bone-like apatite, which enhanced the alloy biocompatibility making it more suitable to use as biomedical implant.
\end{abstract}

Key words: hydroxyapatite, Immersion tests, biocompatibility, Ti heat treatment

\section{Introduction}

Over the past decades, quantitative analyses of basic biomaterial properties have been utilized to better optimize biocompatibility profiles for surgical implant devices. In this regard, relevant correlations between results from pre-clinical and clinical investigations have provided. Critical intercomparisons of cause-effect relationships between the synthetic material properties and longer-term device function. Significant relationships exist between biomaterial/biomechanical properties and the complex aspects of force transfer/motion (fretting and wear) and that is now recognized as critical to many types of biodegradation or corrosion[1].

Titanium and titanium alloys are presently the most important materials for biomedical and dental implant applications. This is due to the formation on their surface of passive film, consisting mainly of amorphous titanium dioxide, which is responsible both for their corrosion resistance and their biocompatibility $[2,3]$.

The alloys currently used as orthopaedic biomaterials are protected from accelerated corrosion rate by a passivation oxide layer that acts like an electrical resistor to retard the anodic dissolution of metal atoms [3].

Alloy modifications of titanium were found to be high effective to improve the corrosion resistance of the materials. Surface modification of Ti and its alloys with calcium- phosphor bio ceramics plays a twin (dual) role both in preventing the release of metal ions (rendering it more corrosion resistant) and also in making the metal surface bioactive[ 4,5$]$

*Directorate of Materials Science, Ministry of Science and Technology

**College of Science for women, University of Baghdad

***Directorate of Chemical Research, Ministry of Science and Technology

$* * * *$ Chemical engineering department, University of Technology 
Ti-5 Al-2.5Fe alloy has been recently enrolled in the list of metallic implant materials, this alloy is of the $\alpha+\beta$ structure type with a microstructure comparable to that of the wrought $\mathrm{Ti}-$ 6Al-4V alloy [6]

Hot rolling accompanied with post heat treatment is the most effective method; this method can be used for strengthening of $\alpha-\beta$ titanium alloys and to refine its morphology. The mechanical properties of titanium alloys are very sensitive to the microstructure, so that the surface finishing and heat treatments of alloy components have a marked influence on technologically relevant properties, including residual stress and composition of $\alpha-\beta \quad$ titanium polymorphous $[7,8]$.

Titanium and its alloys are now being a preferred biocompatible material for bone implants under biomechanical loading conditions. Bioinert titanium based materials are generally encapsulated after implantation in to the living body by fibrous tissue that isolates them from the surrounding bone [9].

The aim of this paper is to obtain the so-called duplex microstructure $(\alpha+\beta)$ in comparison with other microstructures at different heat treatments and its relation for (calcium and phosphor) precipitation on the alloy substrate to increase its biocompatibility.

\section{Material and Methods:}

Alloy Preparation

The alloy was already prepared by Defense Metallurgical Research Laboratories (DMRL) -Hyderabad India as cast alloy. The ingot was obtained in the form of pancake of 600 grams in weight. The cast alloy was rolled in the $\alpha+\beta$ field at $970^{\circ} \mathrm{C}$ to obtain such thick sheet (about $4 \mathrm{~mm}$ ).

\section{Composition and phase analysis}

Table (1) show the contents of all major and minor alloying elements, chemical analysis was done on specimens taken from the cast ingot and the rolled sheet using Atomic Absorption Spectroscopy (AAS 670, Shimadzu, Japan). The phases present in the mirror finish specimen of alloy was identified using XRD (Philips 3121 powder X-ray Diffract meter using $\mathrm{Cu} \mathrm{K} \alpha$ radiation). The indexing data was carried out using XRD Powder Diffraction Files (PDF), version 1992-1993, Ken Laagered.

\section{Heat treatment}

As rolled samples were heat treated by a solid solution heat treatment method (ST) at $970^{\circ} \mathrm{C}$ for 1 hour with different cooling rates (water, air and inside oven), then followed by aging treatment in open-air furnace at $550^{\circ} \mathrm{C}$ for 4 hours for the samples cooled by water and air $[10,11]$. All the heat treatments were carried out in inert environment.

\section{Metallographic techniques}

The microstructures evolution of the heat-treated specimens was investigated by means of optical microscope (Nikon Type 1200-Japan). The specimens for optical observations are prepared following the metallographic techniques used for titanium and its alloys consisting of mechanical polishing with three steps of $\alpha$ alumina $1 \mu \mathrm{m}, 0.3 \mu \mathrm{m}$ and $0.05 \mu \mathrm{m}$ after grinding to 1000 grit surface finish. The specimens are degreased with trichloroethylene and acetone and ultrasonically cleaned using deionizer water. Kroll's reagent containing $10 \mathrm{ml}$ of $\mathrm{HF}, 5 \mathrm{ml}$ of $\mathrm{HNO}_{3}$ and $85 \mathrm{ml}$ of water is used for etching the surface for optical observation.

\section{Immersion Method}

In this test five specimens of approximate dimensions $10 \times 10 \times 3 \mathrm{~mm}$ were selected from the as rolled alloy 
and from treated alloy. The specimens were grinded down to 1000 grit specification. The specimens then weighed using an electronic analytical balance (Scaltel, SPB 31-Germany, read-ability $=0.0001 \mathrm{gm})$. Each of these specimens was entirely immersed in $20 \mathrm{ml}$ of the blood plasma solution in test tubes, and the tube was covered by lid to avoid evaporation. These tubes were kept in water bath at $37^{\circ} \mathrm{C} \pm 11^{\circ} \mathrm{C}$. The weights of the grinded and dried specimens before immersion and washed and dried specimens after 30 days of immersion were measured twice and mean value was determined. Corrosion rate in millimeters per year for the specimens were calculated using the following formula [10]:

Corrosion rate $(\mathrm{mm} / \mathrm{y})=\left(8.76 \times 10^{4}\right)$ $(W) /(d)(A)(t)$

Where: $d=$ alloy density in gram per $\mathrm{cm}^{3}$ (4.52) [ITA 1992-1995 (15)], $A=$ specimen surface area in $\mathrm{cm}^{2}, t=$ exposure time in hours, and $W=$ weight change in gram.

\section{Immersion solution}

For immersion studies twice concentrated synthetic blood plasma solution $(6.8 \mathrm{~g} / 1 \mathrm{NaCl}, 0.4 \mathrm{~g} / \mathrm{l} \mathrm{KCl}, 0.2$ $\mathrm{g} / \mathrm{l} \mathrm{CaCl}, 2.2 \mathrm{~g} / 1 \mathrm{NaHCO}_{3}, 0.126 \mathrm{~g} / \mathrm{l}$ $\mathrm{Na}_{2} \mathrm{HPO}_{4}, 0.026 \mathrm{~g} / 1 \mathrm{NaH}_{2} \mathrm{PO}_{4}$ and 0.1 $\mathrm{g} / \mathrm{MgSO}_{4}$ ) was used with adjusted $\mathrm{pH}$ 7.4

\section{Results and Discussions \\ Phase analysis}

Though there is no JCPDS-ICDD standard for Ti-5Al-2.5Fe alloy, we fitted our results obtained from this analysis according to those reported for the hexagonal $\alpha$ Ti (JCPDS-ICDD file \# 5-682) and cubic $\beta$ Ti (JCPDS-ICDD file \# 44-1288). Also, the results have been compared with the reported diffraction data for Ti-6Al-4V alloy (Scardi et al 1998 and Silva et al 1999 $(5,16))$. Figure 1 show the XRD patterns of Ti-6Al-4V (as standard alloy) and Ti-5Al-2.5Fe alloys. It shows slight change in the $2 \theta$ value of $\alpha$ phase reflections due to the replacement of $\mathrm{V}$ atom by $\mathrm{Fe}$.

\section{Microstructure Evolution}

Hot rolling of $\mathrm{Ti}-5 \mathrm{Al}-2.5 \mathrm{Fe}$ alloy at $970^{\circ} \mathrm{C}$ shows microstructure consisted of globular and acicular $\alpha$ grains (white grains) within a $\beta$-transformed matrix containing equiaxial grains (dark grains). In region where deformation was intense, the microstructure of $\alpha$ was elongated with flow lines (Figure 3 ).

Heat treatment in $\alpha+\beta$ region resulted in recrystallization of the $\alpha$ into an equiaxed morphology designated as primary $\alpha$ in transformed $\beta[14,15]$. The corresponding microstructures of the deformed and solution treated specimens at $970^{\circ} \mathrm{C}$ with different cooling rates are shown in Figures 4.

Specimens quenched from $970^{\circ} \mathrm{C}$ produced structure with less primary $\alpha$ embedded in Martensitic $\alpha^{\prime}$ (Figure $4 a)$, and air-cooling from the same temperatures shows primary $\alpha$ plus acicular $\alpha$ (Widmanstätten) (Figure $4 \mathrm{~b})$. The furnace cooling resulted in increase of the volume fraction of primary $\alpha$ grains and reduces the transformed.

\section{Immersion test}

Figure 5 show the effect of heat treatment temperature and cooling rate on the corrosion rate of alloy after immersion in synthetic blood plasma solution for different periods. Most of the specimens show reduction in the weight loss as the period of immersion progressed from $1-2$ month. The interesting behavior was for the specimen heat treated at $970^{\circ} \mathrm{C}$ and air cooled which had shown weight gain around $2 \times 10^{-4} \mathrm{gm}$ after 2 months of immersion in comparison to its weight before immersion. This kind of behavior confirmed that this treatment can create a microstructure with good elemental distribution able to form a 
stable passive film with higher bonding tendency with calcium and phosphate from the solution to form thick protective layer of calcium and phosphate compounds [11, 12].

When the period of immersion was progressed the weight loss from all specimens was reduced. It has been noticed that the specimen's heat treated at the temperatures $970^{\circ} \mathrm{C}$ and air cooled gained weight after 3 months of immersion compared to its weight before immersion. The others treated specimens immersed for the same period showed reduction in the weight loss but no gain was recorded.

\section{Energy Dispersive \\ X-Ray}

Fluorescence (EDXRF)

The EDXRF patterns of the rolled and heat treated specimens obtained at various cooling rates immersed in solution for a period of 3 months are shown in Figure 6. The patterns show a prominent growing peak compared to as rolled specimen at energy $2.1 \mathrm{KeV}$ and $3.7 \mathrm{KeV}$ values of which arise from the precipitation of phosphate and calcium on the alloy surface. The outer layer shows clearly the growth of phosphate and calcium containing phases [8, 13]. It has been notice that as the heat treatment temperature increased toward the $\alpha / \beta$ transformation temperature, the calcium and phosphate concentration were increased so that the specimen ST at $970^{\circ} \mathrm{C}$ with air cooled shows higher concentration of calcium \& phosphate than other specimens as shown in figure 2. (Won etal 2003 and Jonasova $2004[9,14]$ revealed phosphate and calcium to be present in the surface. So from the above observations, we can conclude that the phosphate and calcium-containing phases formed on the alloys expected to be $\beta-\mathrm{Ca}_{2} \mathrm{P}_{2} \mathrm{O}_{7}$, $\alpha-\mathrm{Ca}_{3}(\mathrm{PO} 4)_{2}$ and calcium titanium oxides $\left(\mathrm{CaTiO}_{3}\right.$ and $\left.\mathrm{Ca}_{2} \mathrm{Ti}_{5} \mathrm{O}_{12}\right)$. The positively charged $\mathrm{Ca}^{2+}$ may act as nucleation site for the formation of hydroxyl apatite (HA) by attaching with the negatively charged $\left(\mathrm{PO}^{4-}\right)^{3-}$ to form $\mathrm{Ca}-\mathrm{P}$ enriched surface layer which crystallizes to form bone-like apatite.

\section{Conclusions}

The Immersion studies clearly reveal that compositional variation in the phases plays a major role on the corrosion behavior of the hot rolled specimens. The specimen ST at $970^{\circ} \mathrm{C} / \mathrm{AC}$ and aged at $550^{\circ} \mathrm{C}$ for 4 hours exhibits superior corrosion behavior due to the absence of selective dissolution of the phases.

The EDXA results show that the precipitation of $\mathrm{Ca}$ and $\mathrm{P}$ compounds on alloy after 3 months of immersion in blood plasma solution appear to have the similar contribution of the apatite formation which have the capability to induce bone like surface (bioactive surface) on alloy substrate.

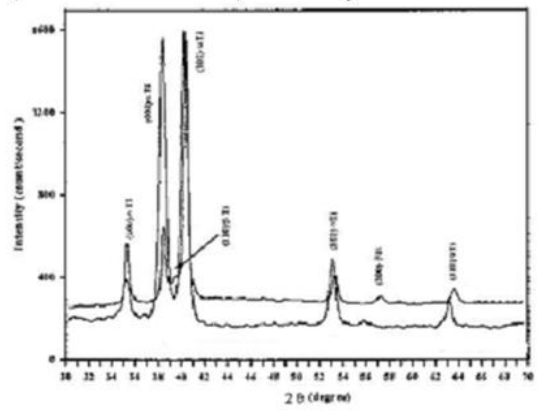

Fig. 1: XRD patterns of (a) Ti-6Al$4 \mathrm{~V}$ and (b) Ti-5Al-2.5Fe alloys.

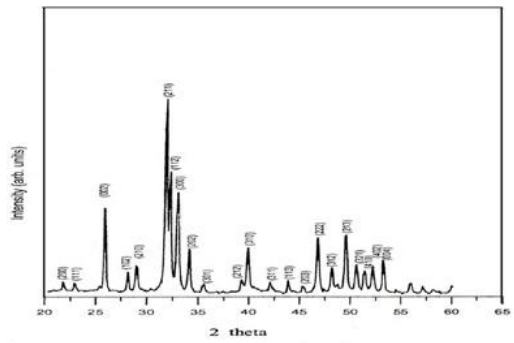

Fig 2: XRD patterns of $\mathrm{Ti}-5 \mathrm{Al}-2.5 \mathrm{Fe}$ after immersion period. 


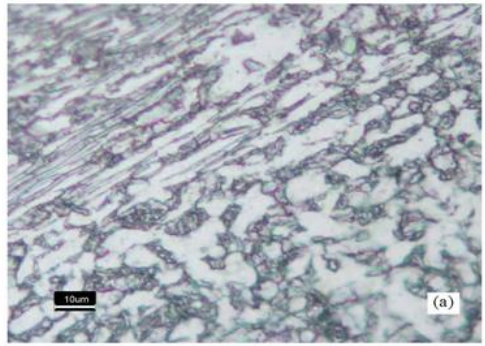

Fig. 3: Optical micrographs showing the microstructure of as-rolled $\mathrm{Ti}$ 5Al-2.5Fe
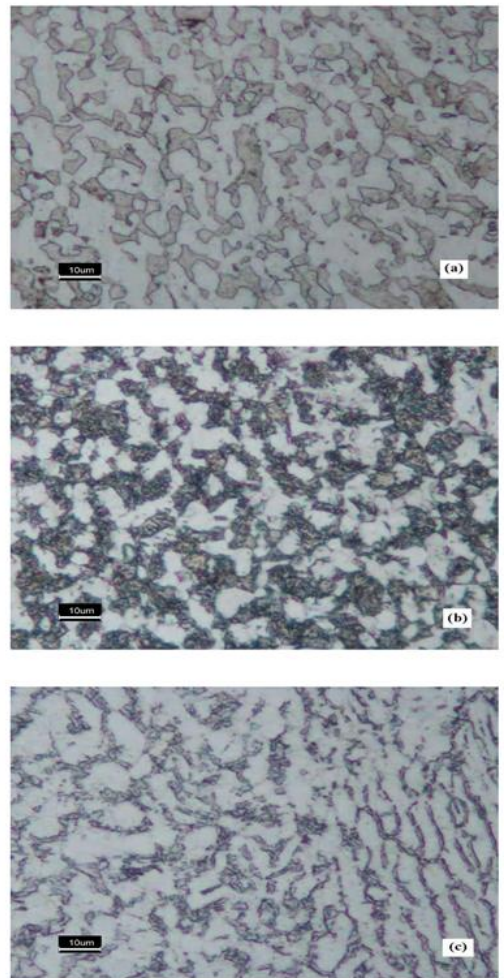

Fig. 4: Optical micrographs of Ti$5 \mathrm{Al}-2.5 \mathrm{Fe}$ alloy solution treated for 1 hour at $970^{\circ} \mathrm{C}$ and cooled at different rates: (a) WQ, (b) AC\& (c) FC.

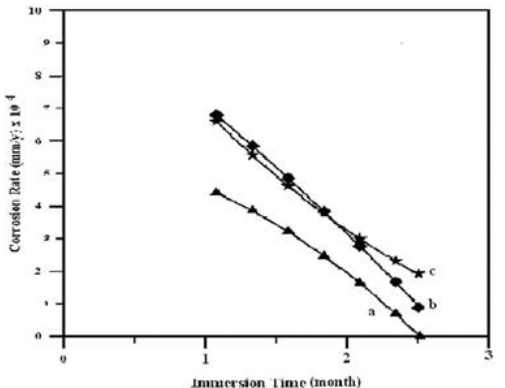

Fig. 5: The variation of corrosion rate with the time for the specimen's solution treated at $970^{\circ} \mathrm{C}$ and cooled at different rates: (a) $\mathrm{AC}$, (b) WQ \& (c) FC.

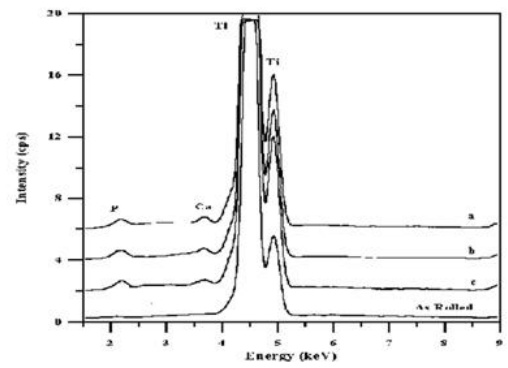

Fig. 6: EDXA patterns of the specimen's heat treated at $970^{\circ} \mathrm{C}$ and cooled at (a) WQ, (b) AC\& (c) FC, compared with as rolled alloy specimens.

\section{References}

1. Venugopalan R and Gaydon J, 2006 "A Review of Corrosion Behavior of Surgical Implant Alloys", Technical Review Note 99-01, Princeton Applied Research.

2. Aziz-Kerrzo Maan, Conroy Kenneth G., Fenelon Anna M., Farrell Sinead T. and Breslin carmel B. 2001, 'Electrochemical Studies on the Stability and Corrosion Resistance of Titanium-Based Implant Materials', Biomaterials, 22; 15311539.

3. Thair L., Kamachi Mudali U., Asokamani R. and Raj B. 2004a, 
"Corrosion Properties of Surface Modified Ti-6Al-7Nb Alloy under Pulsed Plasma Nitriding and Nitrogen ion Implantation Conditions" , Surface Engineering, 20 (1); 11-16.

4. Lavos-Valereto I. C., Wolynec S., Ramires I., Guastaldi A. C. and Costa I. 2004,"Electrochemical Impedance Spectroscopy Characterization of Passive Film Formed on implant Ti-6Al-7Nb alloy in Hank's Solution", J. Mater. Sci., Mater. In Medc., 15; 55-59.

5. Scardi P. and Leoni M. 1998, 'Structural Refinement of $\alpha-\beta$ Polymorphs in Ti-6Al-4V alloy', Surf. Eng, 14 (6); 513-518.

6. Renáta $\mathrm{H}$., Dana $\mathrm{R}$. and Aleš $\mathrm{H}$., 2006, "The calcium phosphate formation on $\mathrm{Ti}$ alloy by precalcification process under static conditions, J. Ceramics Silikáty $50(3) ; 153-158$.

7. Jonasova L., Muller F. A., Helebrant A., Strand J. and Greil P. 2004, "Biomemtic apatite Formation on chemically treated titanium", Biomaterials, 25; 1187-1194.

8. ASM,1981 "Heat Treating of Titanium and Titanium Alloys" Metal Handbook, ed. Bonnie Sanders, ninth edition, (4); 763774.

9. Thair L., Kamachi Mudali U., Asokamani R. and Raj B. 2004b, 'Influence of Microstructural Changes on Corrosion Behavior of
Thermally Aged Ti-6Al-7Nb Alloy', Materials \& Corrosion, 55 (5); 1 - 9 .

10. Schutz Ronald W.1995, 'Titanium', ASTM Annual Series, MNL 20, Philadelphia, USA, 493-506.

11. Simon V., Muresan D., Popa C. and Simon S., 2005 "Microscopic Analysis of Sintered Ti- HAP Implant Materials, J.Optoelect.and Advanc.Matr., 7 (6); 2823-2826.

12. Won-Hoon Song, Youn-Ki Jun, Yong Han and Seong-Hyeon Hong 2004, "Biomemitic Apatite Coatings on micro-arc Oxidized Titania", Biomaterials, Article In press.

13. ITA1992-1995, International Titanium association, Data Bases developed by MATUS, England, Inf, Co. Ltd.

14. Barbosa P.F. and Button S.T. 2000, 'Microstructure and Mechanical Behavior of the Isothermally Forged Ti-6Al-7Nb alloy', J. Materials: Design and Applications, 1; 23-31.

15. Lindemann J. and Wagner L. 1999, 'Microtextural Effect on Mechanical Properties of Duplex Microstructures in $\alpha+\beta$ Titanium Alloys', Mater. Sci. and Eng., 263; 137-14 1.

16. Silva de S.L.R. and Kerber L.O. 1999, 'X-ray Diffraction Measurements of Plasma-Nitrided Ti-6Al-4V', Surface Coating Technology, 116 (119) 342-346. 


\section{تأثير فترة الغمر على سلوك التأكل السبيكة الطبية Ti -5AI - 2.5Fe المعاملة} حراريا

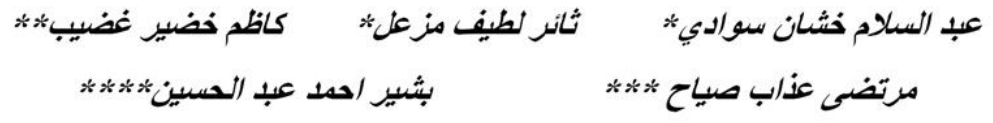

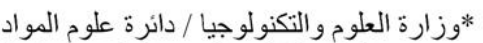

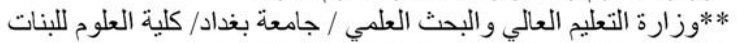

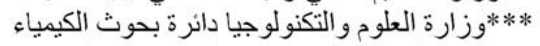

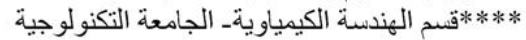

الخلاصة

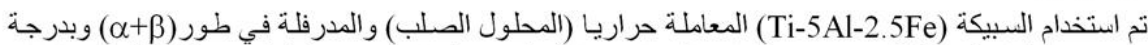

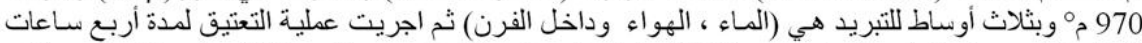

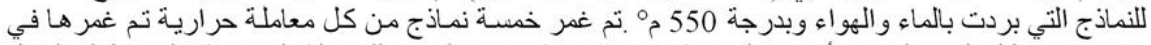

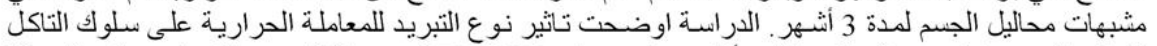

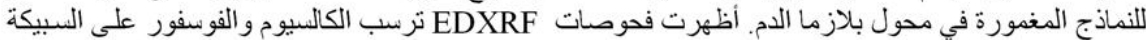
مكونأ طبقة شبيهة بألعظم مما يساعد في زيادة ملائمتها البايولو لونية للاستخدامات الطبية. 